\title{
RANCANG BANGUN E-LEARNING MATA PELAJARAN TEKNOLOGI INFORMASI DAN KOMUNIKASI (TIK) BERBASIS WEB DI SMPN 3 MANDIRAJA
}

\author{
Eko Puji Utomo ${ }^{1}$, Tenia Wahyuningrum ${ }^{2}$, Arief Hendra Saptadi ${ }^{3}$, Dwi Januarita ${ }^{4}$ \\ ${ }^{1,2,3,4}$ Program Studi D-III Teknik Telekomunikasi \\ Akademi Teknik Telkom Sandhy Putra Purwokerto \\ Jl. DI Panjaitan 128 Purwokerto \\ d307147@yahoo.com,tenia_ayu@yahoo.com, ariefhs2002@yahoo.com,dj_kds@yahoo.com
}

\begin{abstract}
ABSTRAK
Makalah ini membahas tentang perancangan dan pembangunan e-learning berbasis web untuk mata pelajaran TIK. Tujuan dibuat web e-learning TIK ini adalah sebagai pelengkap (komplemen) pembelajaran yang sifatnya untuk melengkapi materi pembelajaran, diprogramkan untuk menjadi materi reinforcement (pengayaan) atau remedial bagi peserta didik di dalam mengikuti kebiatan pembelajaran konvensional. Sistem dibangun menggunakan PHP dan database SQL dan dikoneksikan dalam jaringan komputer client-server LAN dengan tujuan agar website yang dibangun menjadi lebih terpusat. Tahapan dalam perancangan dan pembangunan e-learning adalah menggunakan metode waterfall system.Hasil pengujian sistem telah berjalan dengan baik tanpa ada bug/error.
\end{abstract}

Kata kunci : Pembelajaran. Website, Database, E-Learning, jaringan komputer.

\section{PENDAHULUAN}

Perkembangan teknologi informasi dan komunikasi kini senantiasa mengalami peningkatan pesat pada pemanfaatannya yang semakin beragam menyesuaikan dengan kegiatan kegiatan manusia yang modern dan canggih. Salah satu aspek yang menjadi sorotan utama saat ini adalah penggunaan teknologi informasi dan komunikasi di lingkungan pendidikan. John S.Brubacher berpendapat bahwa pendidikan adalah proses pengembangan potensi, kemampuan dan kapasitas manusia yang mudah dipengaruhi oleh kebiasaan, kemudian disempurnakan dengan kebiasaan-kebiasaan yangbaik didukung dengan alat (media) yang disusun sedemikian rupa ${ }^{[6]}$.

Namun harus diakui bahwa metode pendekatan pembelajaran klasikal yang menjadikan guru sebagai sumber belajar utama saat ini masih kurang memadai karena terbatas oleh kelas fisik dan pembatasan waktu pembelajaran yang menyebabkan kurangnya interaksi nyata antara guru, siswa dan media teknologi itu sendiri. Berdasarkan kajian teoritis dan empiris, untuk mengatasi kelemahan tersebut maka penggunaan teknologi informasi dan komunikasi (TIK) dalam pembelajaran menjadi salah satu pemecahan yang sesuai ${ }^{[8]}$.

Fasilitas yang kini menjadi kebutuhan dunia pendidikan saat ini adalah internet. Fasilitas ini memungkinkan dilakukannya pembelajaran jarak jauh, yaitu sekumpulan metode pengajaran yang aktivitas pengajarannya dilaksanakan secara terpisah dari aktivitas belajar. Pada sistem ini, tenaga pengajar dan peserta didik tidak harus berada dalam lingkungan geografis yang sama ${ }^{[2]}$.

Model pembelajaran yang kini menjadi perhatian dunia pendidikan adalah model pembelajaran berbasis komputer dan pembelajaran 
melalui media elektronik (e-learning) berbasis Web-Base Learning (WBL) atau sering disebut online learning. WBL adalah suatu sistem atau proses untuk melaksanakan kegiatan belajar mengajar jarak jauh melalui aplikasi web dan jaringan internet $^{[4]}$. Model pembelajaran ini tidak membutuhkan kelas fisik sebagai media pembelajaran serta tidak memilki batasan waktu pembelajaran.

Tiga fungsi pembelajaran elektronik adalah 1. Sebagai suplemen pembelajaran yang memberikan kebebasan memilih apakah siswa akan memanfaatkan materi pembelajaran elektronik atau menggunakan pembelajaran model konvensional, 2. Sebagai pelengkap (komplemen) pembelajaran yang sifatnya untuk melengkapi materi pembelajaran, 3. Sebagai pengganti (Substitusi) pembelajaran, karena pembelajaran elektronik sepenuhnya digunakan dalam proses pembelajaran.

SMP Negeri 3 Mandiraja merupakan satu dari sekian banyak lembaga pendidikan pemerintah yang belum menerapkan e-learning sebagai salah satu alternatif pembelajaran inovatif yang up to date. Penelitian ini dibatasi untuk mata pelajaran Teknologi Informasi dan Komunikasi (TIK) sebagai satu-satunya mata pelajaran yang mempelajari teknologi informasi dan komunikasi secara mendalam.

\section{TINJAUAN PUSTAKA}

Metode yang digunakan untuk membangun sistem adalah metode waterfall. Metode ini sering disebut dengan classic life cycle. Metode ini melakukan pendekatan secara sistematis dan urut mulai level kebutuhan sistem lalu menuju ke tahap analisis, desain, coding, testing/verification, dan maintenance. Tahap-tahap yang dilalui pada metode waterfall adalah sebagai berikut ${ }^{[5]}$ :

1. Rekayasa dan pemodelan

Pada tahap ini, rekayasa informasi mencakup pengumpulan kebutuhan aplikasi perangkat lunak yang akan dibangun.

2. Analisis Perangkat lunak

Menentukan apakah kegiatan dari sistem engineering dapat diimplementasikan menjadi sebuat sistem informasi atau tidak dan menentukan prosedur-prosedur yang bekerja. Fungsi tersebut meliputi fungsi masukan, fungsi proses dan fungsi keluaran.

3. Perancangan perangkat lunak

Merupakan perancangan perangkat lunak yang dilakukan berdasarkan data-data yang telah dikumpulkan pada tahap sebelumnya. Perancangan tersebut meliput perancangan struktur file, struktur menu, struktur program, format masukan (input) dan format keluaran (output).

4. Implementasi perangkat lunak

Kegiatan yang mengimplementasikan hasil dari perancangan perangkat lunak ke dalam kode program yang dimengerti. 
5. Pengujian perangkat lunak

Pada tahap ini memfokuskan pada logika internal dari perangkat lunak, fungsi eksternal dan mencari segala kemungkinan kesalahan, memeriksa apakah input sesuai dengan hasil yang diinginkan setelah proses berjalan.

6. Pemeliharaan

Pemeliharaan yaitu penerapan secara keseluruhan disertai pemeliharaan jika terjadi perubahan struktur baik dari segi software maupun hardware.

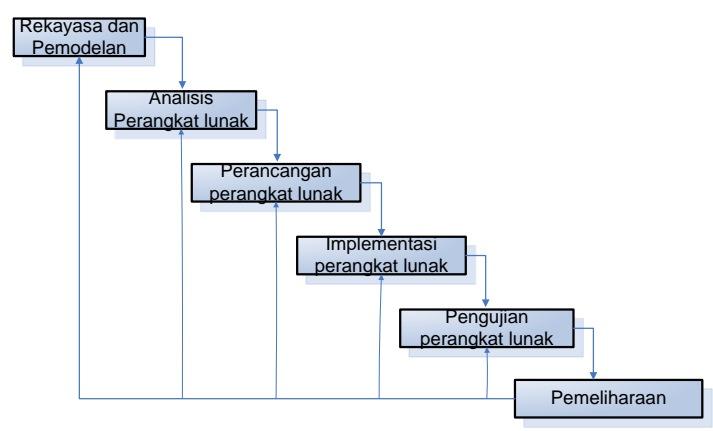

Gambar1. Metode Waterfall

Jaya Kumar C. Koran menyebutkan bahwa pembelajaran e-learning merupakan kegiatan pembelajaran yang memanfaatkan jaringan komputer (Internet, LAN, WAN) sebagai metode penyampaian, interaksi dan fasilitasi serta dukungan oleh berbagai bentuk layanan belajar lainnya $^{[1]}$. Sehingga, materi e-learning disampaikan dalam bentuk halaman web.

Pada tahap pembangunan sistem dalam metode waterfall, web dibuat dengan menggunakan bahasa pemrograman PHP yang juga dikatakan sebagai sebuah server-side embedded script language artinya sintaks-sintaks dan perintah yang diberikan akan sepenuhnya dijalankan oleh server tetapi disertakan pada halaman HTML biasa. PHP merupakan bahasa script yang cocok untuk pengembangan Web dan dapat dimasukkan ke dalam HTML ${ }^{[3]}$.

Aplikasi-aplikasi yang dibangun oleh PHP pada umumnya akan memberikan hasil pada web browser, tetapi prosesnya secara keseluruhan dijalankan di server. Pada prinsipnya server akan bekerja apabila ada permintaan dari client. Dalam hal ini client menggunakan kode-kode PHP untuk mengirimkan permintaan ke server.

Pada tahap implementasi, web e-learning diterapkan pada local Area Network (LAN), yang merupakan jaringan milik pribadi dan memiliki ukuran beberapa kilometer yang mencakup area dalam satu ruang, satu gedung atau beberapa gedung yang berdekatan. Sistem jaringan yang digunakan biasanya adalah menggunakan sistem client-server $^{[7]}$.

\section{ANALISIS DAN DESAIN}

\section{Analisis Kebutuhan Sistem}

Kebutuhan software/hardware

Untuk membangun sistem, diperlukan software XAMPP sebagai paket installer, terutama untuk instalasi sederhana dari Apache server pada PC Windows, MySQL 5.0.27 dan PHP 5.2.0, untuk itu diperlukan hardware dengan spesifikasi minimum 64MB RAM (lebih direkomendasikan menggunakan >64MB), 260MB hard disk (atau direkomendasikan >300MB), Windows 98, ME, Windows NT, 2000, direkomendasikan 
menggunakan Sistem Operasi Windows XP (http://www.a3webtech.com/index.php/xampp.htm 1)

Software lain yang digunakan adalah Adobe Photoshop CS untuk membuat tampilan grafis, Notepad ++ sebagai alat untuk melakukan editing pada syntax pemrograman yang digunakan untuk membangun web, dan Mozilla Firefox sebagai web browsernya.

\section{Desain menu sistem}

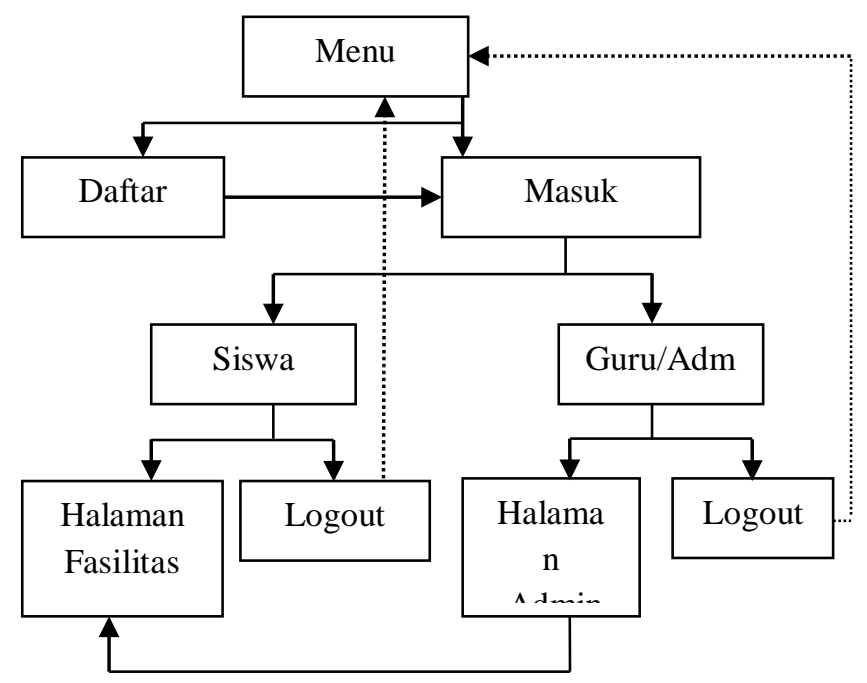

Gambar 2. Desain menu sistem

Halaman fasilitas yang diberikan di dalam sistem e-learning adalah :

- Ujian Online

- Polling

- Forum

- Download-upload

- Laporan

\section{Desain Basisdata}

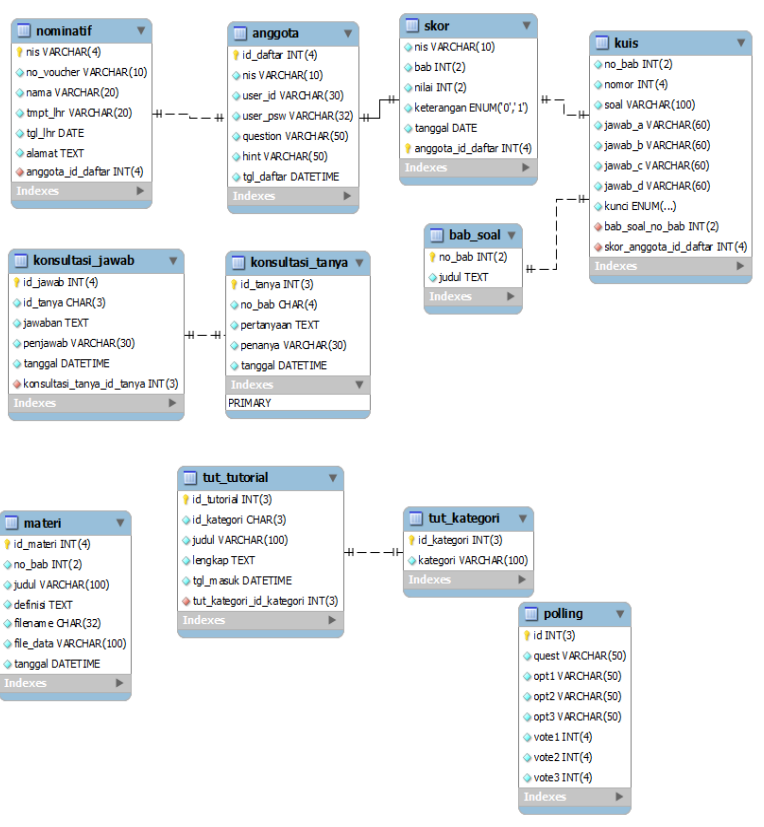

Gambar 3. Desain basisdata

Desain Tampilan Homepage

\begin{tabular}{|l|l|l|}
\hline \multicolumn{2}{|c|}{ Header } & Logo \\
\hline \multirow{2}{*}{ Menu } & Visi Misi & Form \\
& & Login \\
& & \\
\hline \multicolumn{2}{|c|}{ Footer } \\
\hline
\end{tabular}

Gambar 4. Desain tampilan homepage

Cuplikan listing program default.php $<$ ?php if(!\$_GET) \{echo "<h3>VISI DAN MISI </h3>"; include "visi.txt";

switch(\$_GET['pageId'])\{ case '1': include "files/unduh.php"; break; case '2': include "forum/tema.php"; break; case '3': include "miniblog/index.php"; break; case '4': include "forum/response.php"; break; case ' 5 ': include "profil.txt"; break; case '897654309': include "login2.php"; break; \}\} 


\section{Desain jaringan}

Rancangan letak atau layout jaringan yang digunakan adalah memakai jaringan komputer client-server dimana satu komputer bertindak sebagai server dan yang lainnya sebagai client menggunakan topologi star dengan penampang layout sebagai berikut :

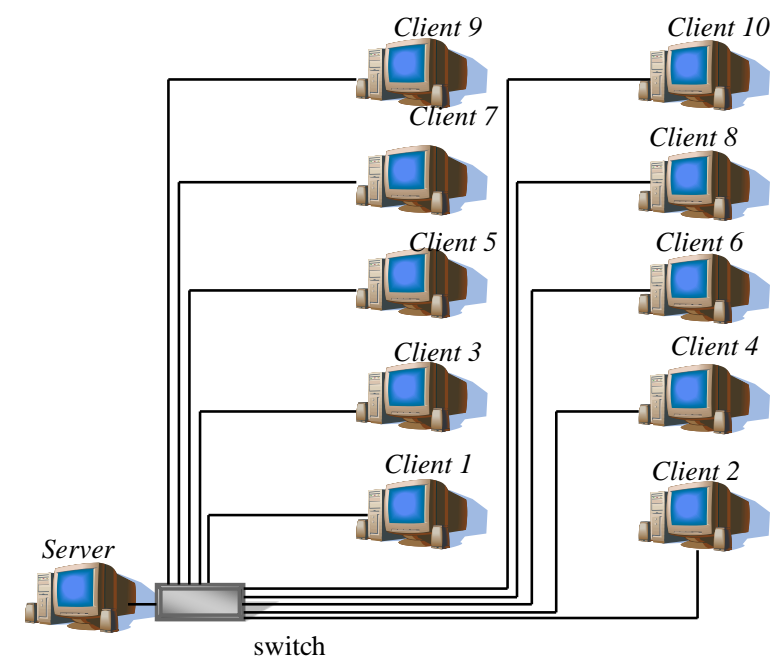

Gambar 5. Desain jaringan

Tabel 1. Tabel IP Address jaringan LAN Lab. Komputer

\begin{tabular}{lllll}
\hline No & $\begin{array}{l}\text { Nama } \\
\text { komputer }\end{array}$ & IP Address & Subnet mask & $\begin{array}{l}\text { Default } \\
\text { gateway }\end{array}$ \\
\hline 1 & server & 192.168 .10 .1 & 255.255 .255 .0 & 192.168 .10 .1 \\
2 & Client 1 & 192.168 .10 .2 & 255.255 .255 .0 & 192.168 .10 .1 \\
3 & Client 2 & 192.168 .10 .3 & 255.255 .255 .0 & 192.168 .10 .1 \\
4 & Client 3 & 192.168 .10 .4 & 255.255 .255 .0 & 192.168 .10 .1 \\
5 & Client 4 & 192.168 .10 .5 & 255.255 .255 .0 & 192.168 .10 .1 \\
6 & Client 5 & 192.168 .10 .6 & 255.255 .255 .0 & 192.168 .10 .1 \\
7 & Client 6 & 192.168 .10 .7 & 255.255 .255 .0 & 192.168 .10 .1 \\
8 & Client 7 & 192.168 .10 .8 & 255.255 .255 .0 & 192.168 .10 .1 \\
9 & Client 8 & 192.168 .10 .9 & 255.255 .255 .0 & 192.168 .10 .1 \\
10 & Client 9 & 192.168 .10 .10 & 255.255 .255 .0 & 192.168 .10 .1 \\
11 & Client 10 & 192.168 .10 .11 & 255.255 .255 .0 & 192.168 .10 .1 \\
\hline
\end{tabular}

\section{IMPLEMENTASI DAN PENGUJIAN}

E-learning berbasis web ini dibangun menggunakan bahasa pemrograman PHP dan diimplementasikan pada pembelajaran TIK di SMPN 3 Mandiraja. Hasil tampilan web adalah sebagai berikut.

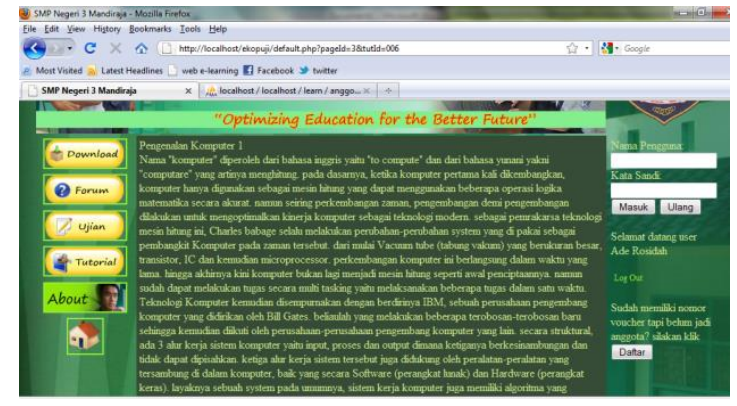

Gambar 6. Tampilan homepage

Pengujian yang digunakan adalah pengujian fungsional, yaitu pengujian yang berguna untuk mengetahui apakah software telah berjalan sesuai dengan fungsinya.

\section{Hasil pengujian}

Tabel 2. Hasil pengujian

\begin{tabular}{|c|c|}
\hline Point pengujian & Hasil \\
\hline $\begin{array}{c}\text { Upload/download } \\
\text { materi }\end{array}$ & Tidak ada error/bug \\
\hline Ujian online & Tidak ada error/bug \\
\hline Polling & Tidak ada error/bug \\
\hline Forum & Tidak ada error/bug \\
\hline
\end{tabular}

Dari hasil pengujian, tidak ada error/bug pada modul fungsi upload/download materi, ujian online, polling dan forum. Artinya semua modul fungsi telah berjalan dengan baik, sebagaimana mestinya.

\section{PENUTUP}

Dari penyusunan penulisan ini, dapat diambil kesimpulan sebagai berikut.

1. Karena keterbatasan biaya, website ini diterapkan pada jaringan komputer dalam ruang lingkup Local Area Network (LAN) dan materi yang di terapkan untuk kelas 8 sebagai sample user.

2. Dari hasil pengujian, web e-learning telah berjalan dengan baik, tanpa ada error/bug pada setiap modul fungsinya. 


\section{DAFTAR REFERENSI}

[1] Herman, Asep, 2010, Mengenal e-learning http://www.jurnalkomputer.com/attachments/008 PENGENALAN\%20E-LEARNING.pdf, diakses tanggal 23 Agustus 2011.

[2] Kurniawan, Wiharsono. 2007. Jaringan Komputer. Yogyakarta:ANDI

[3] Made, W. 2009. Strategi pembelajaran Inovatif Kontemporer. Jakarta: Bumi Aksara.

[4] Praherdhiono, Henry, 2010. Kurikulum TIK di Indonesia(2), http://www.tep.ac.id/berita-118kurikulum-tik-di-indonesia-1.html di akses 24 Oktober 2010.

[5] Reddy, Govindarajalu, Naidu, 2007, A Process Model for Software Architecture, IJCSNS International Journal of Computer Science and Network Security, VOL.7 No.4, April 2007.

[6] Suwarno, W. 2006. Dasar-dasar Ilmu Pendidikan. Jogjakarta: Ar Ruzz.

[7] Uno,H. 2009. Model Pembelajaran. Jakarta:Bumi Aksara.

[8] ___ 2011, __ PHP, http://www.php.net/docs.php. 